\title{
How Supervisors Perceive PhD Supervision - And How They Practice It
}

\author{
Pia Bøgelund \\ Aalborg University, Aalborg, Denmark \\ pb@plan.aau.dk
}

\begin{abstract}
In many Western countries, higher education has experienced a cultural change as a result of increased budgetary constraints, calls for greater accountability, and the greater competition for students. This development has had a profound influence on the working conditions of academic staff and on knowledge production in general at universities. The education of $\mathrm{PhD}$ students is no exception. However, little research has been carried out in regard to the implications of these changes. In particular, the way the supervisors think and react has not been explored.

What do supervisors think about educating PhD students in today's university context? And how and to what extent do they modify their practice based on that understanding? This article seeks to qualify, illustrate, and discuss these questions based on an interview study among twelve experienced supervisors at the Faculty of Engineering and Science at Aalborg University in Denmark.

The data show that it has become more complex to be a PhD supervisor. Three knowledge production perspectives are identified, each embracing a specific university agenda: (1) High quality research; (2) Economically viable and efficient research; and (3) Internationally adapted research. Currently, the second perspective is dominant in the understanding and practice of supervisors to some extent at the expense of the two other agendas. Finally, the consequences of this are discussed.
\end{abstract}

Keywords: $\mathrm{PhD}$ supervision, Practice of $\mathrm{PhD}$ supervisors, Knowledge production, Doctoral student education, Working conditions for academic staff.

\section{Introduction}

Higher education in many western countries has experienced a change in culture relating from budgetary constraints, calls for greater accountability and competition for students (Schniederjans, 2007). In Europe this change in culture has been spurred by the Bologna process (Bianchetti $\&$ Quartiero, 2010) and the associated view of policy makers that higher education institutions are increasingly viewed as "economic en-

Material published as part of this publication, either on-line or in print, is copyrighted by the Informing Science Institute.

Permission to make digital or paper copy of part or all of these works for personal or classroom use is granted without fee provided that the copies are not made or distributed for profit or commercial advantage AND that copies 1) bear this notice in full and 2) give the full citation on the first page. It is permissible to abstract these works so long as credit is given. To copy in all other cases or to republish or to post on a server or to redistribute to lists requires specific permission and payment of a fee. Contact Publisher@InformingScience.org to request redistribution permission. gines" (Sursock \& Smidt, 2010, p. 14).

This development has had a profound influence on the working conditions of academic staff in all areas of their work (Buchanan, Gordon, \& Scuck 2008, Meyer, 2012). The training and development of doctoral students is greatly affected by these new trends. In a Danish evaluation report on the current situation for educating and facilitating the 
careers of young researchers it is stated that each $\mathrm{PhD}$ supervisor, on average, takes on more $\mathrm{PhD}$ students, while at the same time requirements for completion and productivity are increased (Forsknings- og innovationsstyrelsen, 2011). Also, an increasing proportion of PhD students are from international backgrounds. Another defining factor of the current development is that funding for $\mathrm{PhD}$ projects is becoming increasingly more diverse (Forsknings- og innovationsstyrelsen, 2011). PhD students can be fully financed by the university, wholly or partly financed by industry, or by (foreign) scholarships and own funds. In sum, these trends indicate a changing and more complex working environment for the $\mathrm{PhD}$ supervisor. Knowledge production linked to the education of $\mathrm{PhD}$ students is changing profoundly.

In parallel with the current changes in the $\mathrm{PhD}$ supervision area, more manuals are published about $\mathrm{PhD}$ supervision addressed to both supervisors and students. Especially in the UK, literature has been published that focuses on how $\mathrm{PhD}$ students and their supervisors best manage the research process (Delamont, Atkinson \& Parry, 2004; Dunleavy, 2003; Eley \& Jennings, 2005; Rugg \& Petre, 2004; Taylor \& Beasley, 2005). Characteristic of these and similar works is the focus on tools and techniques to improve performance. Other researchers like Handal and Lauvås (2006), Grant (2005), Dysthe (2002), Lindén (1998), and Lee (2008) deal more conceptually with the aim and content of $\mathrm{PhD}$ supervision and accordingly rise above a purely practical level. They discuss different models of supervision. What kind of roles can and do supervisors and their students take on in different situations, stages and disciplines - and with what consequences? Several of these contributions, like Grant (2005), Dysthe (2002), and Lee (2008), are based on empirical inquiries into actual supervisor-student relationships. These studies aim to identify different approaches from which we can learn about the perspectives of both the student and the supervisor.

Looking into the supervision literature at large, however, most of the literature addresses the perspective of the PhD student (of which Gardner (2008) is an example), while the perspective of the supervisor is not made a specific subject of study (Jones, 2013; Wichmann-Hansen, Eika, \& Mørcke, 2007). Especially, there is a lack of knowledge about how the new working conditions for many supervisors affect the way they look upon supervision and how they consequently carry out supervision, not only as an activity in itself, but as one activity among other academic activities at universities. What do supervisors think about educating $\mathrm{PhD}$ students in today's university context? Or to put it more specifically, what is their understanding of the purpose of $\mathrm{PhD}$ related knowledge production? And how does this understanding affect their supervisory practice? These are the two questions that will be addressed in this article. The purpose being to investigate what consequences the current trends have for the working conditions of the PhD supervisors and the education of $\mathrm{PhD}$ students at large.

The first step will be to address what is understood by knowledge production in a historical university context. This forms the theoretical framework of the article. Following this, an interview study will be introduced and the methodology by which to analyse the results. 12 supervisors at the Faculty for Engineering and Science at Aalborg University in Denmark have been interviewed. The empirical data will present how supervisors ideally understand knowledge production today and how they consequently practice supervision in light of this understanding. How the different modes of knowledge production currently evolve and what kind of challenges they run into, given the working context of universities today, will also be investigated. Finally, the findings will be discussed in light of the existing literature and the consequences for the education of PhD students at large.

\section{Knowledge Production in a Historical University Context}

The raison d'être of universities is knowledge production and the education of graduates who possess knowledge, competences, and skills. The education of PhD students is a key element in 
this connection, and the manner in which the individual supervisor perceives the purpose of $\mathrm{PhD}$ education is bound to affect the course of the individual supervisory process. Over time, universities have had different motivations for the production of knowledge, and in the following an outline is presented of the history of knowledge production at universities and thereby the historical evolution in the function and values of universities.

Knowledge production in universities has been on the sociological agenda for quite a while, with the work by Gibbons, Limoges, Nowotny, Schwartzman, Scott, and Trow (1994) marking an important highpoint, as they introduce a new mode of knowledge production based on market demands, different from the traditional knowledge production based on disciplines. Taking a point of departure in this division and inspired by Wenneberg $(2001)$, Barnett $(1994,2011)$ and Jamison, Christensen, \& Botin (2011) it is possible to identify three different perspectives on knowledge production as seen through sociology of education and a historical approach: an academic, a market oriented, and a changing society perspective. The two first perspectives are from Wenneberg (2001), while the last perspective is inspired by Barnett (1994) and Jamison et al. (2011). See Table 1.

Table 1. Three perspectives on knowledge production

\begin{tabular}{|c|c|c|c|}
\hline & $\begin{array}{l}\text { Knowledge production } \\
\text { in an academic per- } \\
\text { spective }\end{array}$ & $\begin{array}{l}\text { Knowledge production } \\
\text { in a market perspective }\end{array}$ & $\begin{array}{c}\text { Knowledge production } \\
\text { in a changing society } \\
\text { perspective }\end{array}$ \\
\hline $\begin{array}{l}\text { The purpose } \\
\text { of the univer- } \\
\text { sity }\end{array}$ & $\begin{array}{l}\text { To produce true } \\
\text { knowledge and to edu- } \\
\text { cate graduates who have } \\
\text { acquired this knowledge }\end{array}$ & $\begin{array}{l}\text { To produce believable } \\
\text { and useful knowledge }\end{array}$ & $\begin{array}{l}\text { To produce believable } \\
\text { and useful knowledge } \\
\text { for a globalised world }\end{array}$ \\
\hline \multirow{2}{*}{$\begin{array}{l}\text { Concept of } \\
\text { knowledge }\end{array}$} & $\begin{array}{l}\text { Knowledge as true, } \\
\text { justified conviction }\end{array}$ & $\begin{array}{l}\text { Knowledge as a social } \\
\text { element }\end{array}$ & $\begin{array}{l}\text { Knowledge as a source of } \\
\text { empowerment and change }\end{array}$ \\
\hline & $\begin{array}{l}\text { Production of } \\
\text { knowledge is central }\end{array}$ & $\begin{array}{l}\text { Employing knowledge is } \\
\text { central }\end{array}$ & $\begin{array}{l}\text { Value-based, contextual } \\
\text { exchange of knowledge is } \\
\text { central }\end{array}$ \\
\hline $\begin{array}{l}\text { University as } \\
\text { part of society }\end{array}$ & $\begin{array}{l}\text { Universities must pro- } \\
\text { duce true knowledge and } \\
\text { add to the collective } \\
\text { knowledge of society }\end{array}$ & $\begin{array}{l}\text { Universities must take } \\
\text { part in creating economic } \\
\text { growth and welfare }\end{array}$ & $\begin{array}{l}\text { Universities must create } \\
\text { change agents in a world } \\
\text { facing global challenges }\end{array}$ \\
\hline
\end{tabular}

The classical perspective on universities - the academic - is that universities must produce true knowledge and educate graduates who have acquired this knowledge (Wenneberg, 2001). To produce true knowledge is a goal in and of itself. It is professionalism for the sake of professionalism. Focus is on professional norms and values. How this knowledge is put to use and by whom is not central to this perspective; knowledge and learning is, on the contrary, dominated by theoretical issues and traditional academic virtues (Barnett, 2011). All universities founded earlier than the mid-twentieth century can safely be assumed to be born with this perspective.

Around the mid-twentieth century, a new understanding of science and technology came into being, which gradually affected knowledge production at universities (Jamison et al., 2011, p. 13). The background for this new understanding is to be found in an increased societal need for innovation, and that graduates are able to employ their knowledge through the acquisition of skills and competences - not the least through their role as founders of their own businesses (Bar- 
nett, 1994). This new perspective, knowledge production in a market perspective, is centred on profitability, entrepreneurship, and innovation - to make money and to do business. Ideas and inventions lead to the development of new products, which, in the end, generates profit. The usage of the knowledge produced and the dialectic relationship between usage and the production of knowledge plays an increasingly central role at universities (Jamison et al., 2011, p. 14; Wenneberg, 2001, p. 40).

Parallel to this, there is a change in the understanding of what knowledge is and where it is created. The concept of knowledge is widened, and knowledge creation is now possible through the collaboration of universities and businesses. The concept of knowledge thereby enters the domain of social constructivism. Knowledge is no longer true per se; it is a product created through a more or less reassuring process (Wenneberg, 2001, p. 41). Universities are transformed from being a self-referent producer of knowledge into one of several actors cooperating to create growth and profit. In this era, university leadership is changed according to "New Public Management", where leaders are seen more as employees and given extended powers and where state regulation is permeated by the realities of the market (Barnett, 2011). New collaborations, such as science parks, research shared between universities and companies, and university staff working as consultants, can be seen as results of the market perspective. This development is not equally distributed within the universities. Knowledge, ideas, and disciplines carrying profitable perspectives have more opportunities than other subject areas, which do not have the same business appeal, as such different disciplines and faculties increasingly experience different opportunities, with the technical disciplines as the ones with most opportunities.

The third perspective - knowledge production in a changing society perspective - originates in social, popular movements, which have occasionally set the agenda in the western world concerning basic issues in life (Jamison et al., 2011, p. 22). Examples include peace movements, women's liberation movements, and environmental movements from the sixties and onwards. These movements have attempted to address global democratic, environmental, or discrimination issues and to promote cooperation. Development and cross-disciplinary and cross-cultural exchange of knowledge are central characteristics of knowledge production in this perspective.

The primary characteristic is that knowledge, which is produced and employed, brings real change and improvement, which is directed toward increased equality, networking, democracy, and liberation (Barnett, 1994). This perspective demands involvement and commitment. It focuses on integrity and the development of personality and identity as part of academic discourse.

The three perspectives contain different views on science. How does new knowledge emerge, what is important to notice regarding science and technology, and which role can and should science (and technology) have in society? The two first perspectives, the academic perspective and the market perspective on the production of knowledge, are described by Jamison et al. (2011) as far more dominant discourses in society than the third perspective. At universities, the academic perspective has traditionally been dominant, but is continually facing competition from state regulation with the purpose of increasing the production of graduates and articles and preparing universities for the private sector's demand for more work- and practice-oriented graduates and research. Jamison et al. (2011) point out that the classical academic perspective often assumes the role of a defensive reactionary protest, whereas the changing society perspective is considered a creative and liberating protest.

It is the intention to relate the theoretical framework above to a specific empirical case, but before that, the case and the design of the interview procedure is presented. 


\section{The Empirical Case - Design and Discussion of Method}

The empirical material of this article derives from a series of interviews in 2012 among $12 \mathrm{PhD}$ supervisors at two science school programs at the Faculty of Engineering and Science at Aalborg University in Denmark. The purpose of the interview study has been to explore how supervisors experience and handle some of the earlier mentioned challenges to supervision: an increased number of $\mathrm{PhD}$ students, a higher percentage of $\mathrm{PhD}$ students with an international background, budget constraints, generally shorter deadlines, and more stakeholders with an interest in the results of the PhD projects. The interview study was part of a greater project financed by Aalborg University and the Agency for Competence Development in the State Sector: "Competence Development of the PhD Supervisor in an Intercultural Reality" (Bøgelund, 2011).

The two science school programs have been chosen because both have a lot of international students enrolled, and therefore both are at an advanced stage of transition. The term "International" covers all nationalities except Danish. Both programs contain large groups of Asian and Middle Eastern students. Southern and Eastern European and Indian students are also relatively wellrepresented. The one program balances between natural and social scientific traditions (Program A), while the other program is rooted in classical natural science (Program B). Program A has only recently been through a transitional process, during which the number of $\mathrm{PhD}$ students and the percentage of international students have increased significantly. The transition has taken place over a very short time span of only a few years. Program B started its transition at an earlier time allowing for a more gradual process. The choice of these two programs, thereby, offers the opportunity to look at an ongoing and a finished transitional process - at the same time keeping an eye on the impact resulting from the kind of field in question.

The involved supervisors represent a wide professional spectrum. We have consciously chosen supervisors from different scientific groups. On the one program, the supervisors were chosen on the background of a complete list of supervisors and $\mathrm{PhD}$ students according to their field of study. On the other program, supervisors were chosen based on advice from well-informed senior researchers, since a complete list did not exist on this program. All the supervisors have experience with international $\mathrm{PhD}$ students and most have or have had more than five $\mathrm{PhD}$ students. To a large extent, the interview can be seen as an overview of best practice in its field, given the fact that the interviewed supervisors are among the most experienced professors and associate professors. All in all 12 supervisors have been interviewed, six from each program, 11 males, one female. Seven supervisors are native Danish, three others from western cultures, and the last two are from eastern cultures. All the non-Danish supervisors have been in Denmark 10 years or more. The impacts of national cultures on these none-Danish supervisors were there, although not to an extent that it was possible to discuss it with any certainty or draw conclusions based on it.

Supervisors have been asked about their own practice, the dominant practice in their immediate professional surroundings, attitudes and expectations to $\mathrm{PhD}$ students and their own perception of the style of supervision, and their challenges in and experience of supervision - especially the supervision of international PhD students. The analytical framework is inspired by Kolmos' and Holgaard's (2007) model for situational supervision, and Argyris' and Schön's (1974) concepts of 'theory-in-use' and 'espoused theory' and may be summed up in Figure 1:

The focus is on the supervisor's self-image and understandings of own practice, attitudes and expectations, especially of international $\mathrm{PhD}$ students. Figure 1 was presented to each supervisor prior to his or her interview in order to establish a common framework for the interview. No further elaboration of the terminology has been offered; thereby supervisors were given the opportunity for an individual approach to the subject. To obtain an in-depth and private situation the interviews have been centred around an individual semi-structured questionnaire founded on the themes of the figure. Some themes have taken priority in individual interviews depending on the 
interviewed supervisor. Each interview extended from one to two hours in duration. The interviews were recorded as sound files and a detailed summary of them was made immediately after each interview, by the person who performed the interview. Participants were asked to comment on, and validate quotes which were central to their discussion (Olsen \& Pedersen, 1997).

The supervisor's perception of own style of supervision, challenges and experiences

Practice - who does what, when and why?

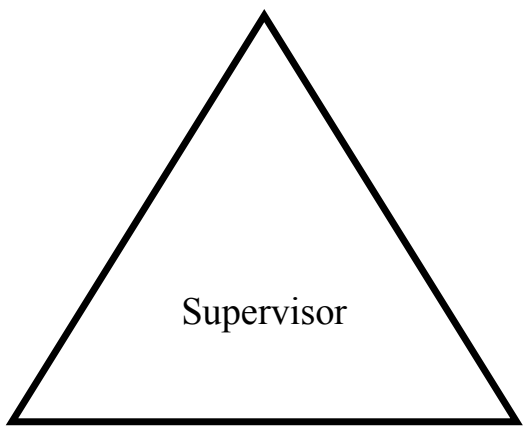

Attitude and expectations towards the PhD student

Context: More PhD students, Practice in professional surroundings, Management

Figure 1: The analytical framework used for the interview study

On the basis of these summaries, two approaches for the analysis were employed. First, the summaries were read through, and intuitively interesting statements were noted. Second, all summaries were broken down and rearranged according to the analytical framework: Statements regarding context were placed together, as were statements regarding style of supervision, challenges, and experience, statements regarding attitudes and expectations of the $\mathrm{PhD}$ student, and statements regarding actual practice. Following this, the statements of each supervisor were scrutinised in the light of the three knowledge production perspectives: How did each supervisor perceive the purpose of knowledge production? What concepts of knowledge were advocated for? How should the knowledge produced contribute to society? On the basis of this what was considered important to strive for or do as a supervisor? What was considered unimportant to strive for or do or directly counterproductive? Often statements concerning the value of other ways to perceive or act as supervisor would shed light on the actual supervisor in question. Parallel with this process the similarities and differences between different supervisors and between the two research programs were identified, and thus the context were taken into consideration. Passages relevant for quoting have been transcribed and language corrections made. Quotes in Danish have been translated into English by the author.

In the following three sections the results of the study are presented. First the supervisors' understanding of the purpose with $\mathrm{PhD}$ related knowledge production is identified. Then how they actually practice based on that understanding. Finally, an overall picture of where practice is heading and what challenges are experienced by individual supervisors is presented.

\section{Supervisors' Views on Knowledge Production}

The supervisors' statements regarding their more or less conscious view on knowledge production are illustrated in Table 2. The theoretical distinction between the three perspectives on knowledge production has been the determining factor in distributing the statements. As far as 
possible, the supervisors' own words have been used - this is indicated through the use of italics. As presented here, the perspectives are ideal types in order to underline the three perspectives. Most supervisors make statements which can be related to all three perspectives. None of the supervisors fit perfectly into one perspective or another. Likewise, it is important to stress that all statements made by the supervisors can be related to one of the three perspectives. Table 2 shows what is central to and focused on in each of the perspectives on supervision. It also shows, what is not given priority or considered downright unwanted.

Below, the three perspectives are further illustrated through three quotes from three supervisors who have been inspired by, respectively, the academic, the market oriented, and the changing society perspective. The quotes show what is central to each perspective regarding the supervision of $\mathrm{PhD}$ students: professional passion, the usefulness of the $\mathrm{PhD}$ student, and the wish for a cultural revolution. First, an academically oriented supervisor:

"I truly enjoy the PhD process and the environment surrounding it. I find it exciting working with people who venture on such journeys of discovery... In particular, I value the foundation of a critical perspective... to watch someone turning into an academic... that they are inspired and excited. ... It is not sufficient for them just to pass through the system... If their passion isn't there, why are we here? ... One of the rewards [of supervision] is sharing that [passion]." (Academically oriented supervisor, V1 A).

Then a market oriented supervisor:

"I like to work with issues from industry, because such issues are real... People in industry typically don't have the time to go into detail with anything... and that's where PhD students come in handy... Now, I am seeing things from a business perspective... The university gets [funding and a connection to the real world.] [PhD students] are a skilled resource. ... it [is] a far better investment for me to spend some of my time on a young, skilled person, making that person do, what I should otherwise have done." (Market oriented supervisor, V1 B).

And finally a supervisor with a changing society perspective:

"If I get a Danish PhD student, I would welcome that person anytime, but I also think that we have an obligation to other countries... Basically, one must retain that ... in the three to four years one is here [as an international PhD student] it is possible to learn a lot ... The goal is not just the production of researchers, it is also producing people who can be innovative in their systems... We are taking part in a cultural revolution, when we try to make them a little more democratic, a little less prejudiced, a little more Danish. I think that is important to keep in mind." (Supervisor with a changing society perspective, V2 A).

The statements in the table and the three quotes show the core of each perspective on knowledge production in a university context. The individual supervisor may, as mentioned, contain several facets, which also includes the three quoted supervisors. It is more the mix in the individual supervisor - and across supervisors - which is of interest. 
Table 2. Ideal typical view as a $\mathrm{PhD}$ supervisor

\begin{tabular}{|c|c|c|c|}
\hline & $\begin{array}{l}\text { Knowledge production } \\
\text { in an academic } \\
\text { perspective }\end{array}$ & $\begin{array}{l}\text { Knowledge production } \\
\text { in a market } \\
\text { Perspective }\end{array}$ & $\begin{array}{l}\text { Knowledge production } \\
\text { in a changing society } \\
\text { perspective }\end{array}$ \\
\hline \multirow{5}{*}{$\begin{array}{l}\text { What is } \\
\text { important or } \\
\text { positive } \\
\text { according } \\
\text { to this } \\
\text { perspective? }\end{array}$} & $\begin{array}{l}\text { Good discussions and } \\
\text { good cooperation }\end{array}$ & $\begin{array}{l}\text { Cooperation with } \\
\text { industry regarding real } \\
\text { problems }\end{array}$ & $\begin{array}{l}\text { Creating positive change } \\
\text { in student's homeland }\end{array}$ \\
\hline & $\begin{array}{l}\text { Professional prestige in } \\
\text { being a } \mathrm{PhD} \text { supervisor }\end{array}$ & $\begin{array}{l}\text { Contributing to local } \\
\text { Inational growth and } \\
\text { welfare }\end{array}$ & $\begin{array}{l}\text { Initiating learning for } \\
\text { the sake of the students }\end{array}$ \\
\hline & $\begin{array}{l}\text { Make one's mark on } \\
\text { someone and make use of } \\
\text { the best people in one's } \\
\text { own system }\end{array}$ & $\begin{array}{l}\text { Resource optimization: } \\
\text { The production of many } \\
\text { PhDs, articles } \\
\text { and patents }\end{array}$ & $\begin{array}{l}\text { Educating fully-fledged } \\
\text { academics - critical and } \\
\text { self-motivated }\end{array}$ \\
\hline & $\begin{array}{l}\text { Contributing academically } \\
\text { in a specific field and } \\
\text { making an } \\
\text { engaged difference }\end{array}$ & $\begin{array}{l}\text { Staying updated and } \\
\text { supporting own research } \\
\text { with the aid of young } \\
\text { people }\end{array}$ & $\begin{array}{l}\text { The obligation to other } \\
\text { countries regarding the } \\
\text { spread of problem } \\
\text { based learning (PBL), } \\
\text { democracy and } \\
\text { humanistic ideals }\end{array}$ \\
\hline & $\begin{array}{l}\text { Professional passion for } \\
\text { the sake of the profession. }\end{array}$ & $\begin{array}{l}\text { Using PhD supervision } \\
\text { for boosting one's } \mathrm{CV}\end{array}$ & $\begin{array}{l}\text { The pedagogical } \\
\text { challenge of helping } \\
\text { people through }\end{array}$ \\
\hline \multirow{5}{*}{$\begin{array}{l}\text { What is } \\
\text { unimportant or } \\
\text { negative } \\
\text { according } \\
\text { to this } \\
\text { perspective? }\end{array}$} & $\begin{array}{l}\text { Argumentation based on } \\
\text { status }\end{array}$ & $\begin{array}{l}\text { Cultural adjustment and } \\
\text { nursing of the individual } \\
\text { PhD student }\end{array}$ & $\begin{array}{l}\text { Narrow focus on the } \\
\text { time it takes to educate } \\
\text { PhD students }\end{array}$ \\
\hline & $\begin{array}{l}\text { Dependent and unmotivat- } \\
\text { ed students. }\end{array}$ & $\begin{array}{l}\text { Prioritizing the academic } \\
\text { challenge }\end{array}$ & $\begin{array}{l}\text { To run things as an } \\
\text { assembly line } \\
\text { in a factory }\end{array}$ \\
\hline & $\begin{array}{l}\text { Deliverables at the cost of } \\
\text { theoretical and } \\
\text { methodological substance }\end{array}$ & $\begin{array}{l}\text { The education of our } \\
\text { most difficult students } \\
\text { without the allocation of } \\
\text { necessary resources }\end{array}$ & $\begin{array}{l}\text { Primarily using } \mathrm{PhD} \\
\text { students as manpower in } \\
\text { the supervisor's own } \\
\text { projects }\end{array}$ \\
\hline & $\begin{array}{l}\text { Productivity } \\
\text { considerations control the } \\
\text { education of } \mathrm{PhDs}\end{array}$ & $\begin{array}{l}\text { Narrow focus on } \\
\text { university economy and } \\
\text { national brain drain }\end{array}$ & $\begin{array}{l}\text { Looking at } \mathrm{PhD} \text { students } \\
\text { as research assistants }\end{array}$ \\
\hline & Project management & $\begin{array}{l}\text { A too large percentage of } \\
\text { foreigners }\end{array}$ & \\
\hline
\end{tabular}




\section{Supervisors' Practice in Light of Each Perspective}

As Table 3 shows, the individual supervisor's view on knowledge production is of great importance to how he or she practices as a supervisor. It is not without consequence how a person is oriented in relation to the perspectives on knowledge production. It affects the approach, the time spent, and the trust in the individual $\mathrm{PhD}$ student. In the table, examples of concrete activities have been added. These are not unique to the single perspective. The same activity may take place within all three perspectives, but with varying importance and meaning assigned to it.

\section{Table 3. Ideal typical practice as a PhD supervisor}

\begin{tabular}{|c|c|c|c|}
\hline & $\begin{array}{l}\text { Knowledge production in } \\
\text { an academic perspective }\end{array}$ & $\begin{array}{l}\text { Knowledge production } \\
\text { in a market perspective }\end{array}$ & $\begin{array}{l}\text { Knowledge production in a } \\
\text { changing society perspective }\end{array}$ \\
\hline Forum & $\begin{array}{l}\text { The academic, professional } \\
\text { field }\end{array}$ & $\begin{array}{l}\text { The market oriented, } \\
\text { professional field }\end{array}$ & $\begin{array}{l}\text { The social and cultural, } \\
\text { professional field }\end{array}$ \\
\hline $\begin{array}{l}\text { Expectati } \\
\text { on }\end{array}$ & $\begin{array}{l}\text { Quality, high level and } \\
\text { independence }\end{array}$ & $\begin{array}{l}\text { Quality, independence, drive } \\
\text { and ability to fit in }\end{array}$ & $\begin{array}{l}\text { Finishing is primarily a } \\
\text { question of right support }\end{array}$ \\
\hline Focus & $\begin{array}{l}\text { Motivation and professional } \\
\text { guidance in } \\
\text { relation to potential }\end{array}$ & Producing useful results & $\begin{array}{l}\text { Understanding, reflecting on } \\
\text { and employing theory in a } \\
\text { new context }\end{array}$ \\
\hline Role & Professional sparring partner & Project leader & All-round facilitator \\
\hline \multirow[t]{4}{*}{$\begin{array}{l}\text { Example } \\
\text { s of activ- } \\
\text { ities }\end{array}$} & $\begin{array}{l}\text { Long, open discussions } \\
\text { without suggestions for } \\
\text { research questions }\end{array}$ & $\begin{array}{l}\text { Actively controlling - often } \\
\text { part of a differentiated su- } \\
\text { pervisory system with two } \\
\text { supervisors }\end{array}$ & $\begin{array}{l}\text { Actively facilitating and } \\
\text { present at the start. Scaffold- } \\
\text { ing exercises and framework }\end{array}$ \\
\hline & $\begin{array}{l}\text { Critical, theoretical and } \\
\text { methodological dialogue }\end{array}$ & $\begin{array}{l}\text { Recruitment according to } \\
\text { quality, attitude and cultural } \\
\text { adaptation }\end{array}$ & $\begin{array}{l}\text { Developing a good social } \\
\text { and professional environ- } \\
\text { ment around the students }\end{array}$ \\
\hline & $\begin{array}{l}\text { Career management through } \\
\text { networking }\end{array}$ & $\begin{array}{l}\text { Personnel management - } \\
\text { among others in relation to } \\
\text { skill and adaptation }\end{array}$ & $\begin{array}{l}\text { Employing humour and } \\
\text { knowledge of Danish cul- } \\
\text { ture }\end{array}$ \\
\hline & $\begin{array}{l}\text { Possible promoter in relation } \\
\text { to the academic system }\end{array}$ & $\begin{array}{l}\text { Founding of self-motivating } \\
\text { communities and mentoring }\end{array}$ & $\begin{array}{l}\text { Global cultural exchange } \\
\text { programs and workshops }\end{array}$ \\
\hline
\end{tabular}

The academic perspective is often characterized by a mutual, professional relationship, where meetings with the supervisor are spent in discussion of professional terms and challenges. It is typical to this perspective, that extra-professional matters are not part of the supervisory function. To the extent that social and cultural aspects are touched upon, this often takes place outside formal meetings with the supervisor; during coffee breaks, or travelling to or from conferences, and more on a curious level than as part of the supervisory process. In this perspective, the $\mathrm{PhD}$ student is generally met with high expectations regarding commitment and independence. Passion and a professional, critical sense are of the utmost importance. The supervisor may see it as part 
of supervising to introduce the $\mathrm{PhD}$ student to the supervisor's own network and guide the young person in the direction of professionally interesting research environments and conferences.

A supervisor adhering to the market perspective will primarily see him or herself as a project leader, and the relation to the PhD student may contain certain similarities to the relation between an employer and an employee. It is the supervisor who lays down the framework for the project and who takes control at the beginning of the project. The $\mathrm{PhD}$ student is a work resource who is expected to contribute with his or her own creativity and ideas within the given framework. Therefore recruitment and ongoing personnel management and care are of great importance. Often several $\mathrm{PhD}$ students are tied to the same project or field and efforts are directed towards fulfilling market and academic demands according to the terms of the cooperation. Typically, the supervisor will also focus on rationalizing academic and market production. This can be achieved by sharing supervision between several supervisors with different competences. Establishing mentoring where research fellows support newly arrived $\mathrm{PhD}$ students or establishing professional environments with widespread use of sparring and co-writing may also be part of the supervisor's practice.

A supervisor adhering to the changing society perspective mainly perceives the reflective education of the PhD student and his or her ability to master change agency as part of the supervisor's tasks. The supervisor does not expect a priori that the $\mathrm{PhD}$ student is critical, reflexive, and highly independent. As a consequence, this type of supervisor has far greater interest in the professional, cultural, and social development of the $\mathrm{PhD}$ student than supervisors adhering to the two other perspectives, and this supervisor generally supervises persons in their entirety, including formation and identity. This is an aspect which especially comes into play in relation to international $\mathrm{PhD}$ students, who are foreign to the pedagogical and democratic practice that Danish universities, not the least Aalborg University, are proponents of. As the aforementioned quote shows, these supervisors are of the opinion that they should contribute to the education of reflective and innovative $\mathrm{PhD}$ students, who can make a change in their homeland. Activities supporting this goal are the establishment of a strong professional and social community; introduction to Danish values, modes of operation and Danish language; widespread use of practice exercises, structuring and matching of expectations; and a high degree of availability. In a somewhat larger context, cultural exchange programs, workshops, and cooperative projects on a global scale provide valuable cultural insight and partners for cooperation.

\section{Domination and Challenges of the Different Perspectives}

In line with Jamison et al (2011), it is the market perspective which dominates among the twelve interviewed supervisors and the changing society perspective which is least well represented. To some extent, all supervisors represent the academic perspective, even if its importance is negligible in some cases. It is also worth noting, that supervisors who adhere to the academic perspective and the socially restructuring perspective fit well with Jamison et al (2011), regarding how - respectively - they relate to the dominating market principle - reactively or more proactively. The supervisors most strongly inspired by the academic perspective are in opposition to the dominant trend; they are unable to see anything constructive in the present development. The supervisors adhering to the socially restructuring principle are also able to see potential in the present development (see quotes below). The combination of perspectives in supervisors is diverse. Even if the market perspective and the changing society perspective contain opposing principles, there are examples of supervisors who are inspired by both perspectives, typically with one perspective dominating. The perspectives are not mutually exclusive, even if a combination may give rise to internal balancing problems.

When one looks at the supervisors by program, there is a noticeable difference between the two groups of supervisors. Pluralism is more obvious in the science school program, which balances 
between natural and social scientific traditions, while the market perspective clearly dominates on the other program, which is rooted in classical natural science. If one looks at the individual research groups, which are tied to the two programs, it is possible to identify entire environments which, primarily, are dominated by a particular perspective or by a particular combination of perspectives. The programs are also influenced by the amount of time available to adjust to their new framework. Frustrations regarding the short time span for transition are noteworthy at program A. It also makes an impression that the role of professional, collegial sparring partner is forced in the direction of the role as project leader. At program B, the role of project leader is more widely accepted - which must, however, be seen in the light of the program's general conditions, with cooperation with the business sector and large scale projects. Everyday practice under the new framework is more well-established at program B. Routines connected with recruiting and making a large team of international and Danish $\mathrm{PhD}$ students function as a group are more established.

Supervisors report on different challenges in their supervision depending on which perspective they are most inspired by. Supervisors most inspired by the academic perspective are challenged, when the professional angle is in conflict with other interests or spheres of interest. It could, for instance, be when managerial dispositions threaten to undermine professional quality:

"This foolishness, that a PhD should be granted for writing three articles - that is setting the bar too low ... It is important, that you learn how to combine theoretical and methodological considerations ... At this faculty .. many say... that now PhD students should take part in making "deliverables", and later we call them theses ... the basics are neglected." (Supervisor 3, A)

"The concept of a PhD is changing ... everything is about writing publications ... before they spend time constructing an understanding of literature ... and there is an increasing pressure from management, that they should finish on schedule.. [As a supervisor] you have to decide, if you want to stick with old fashioned values or if you want to become more of a project leader ... Like in "I've got the money, this is what we must do" ... What fills me is that the system has unrealistic expectations. Suddenly we have a lot of PhD students who exert pressure on our way of working ... With the two who finished before Christmas, we followed a more traditional path. We had very long, very open discussions, where we only encouraged them ... We never suggested what their research questions should be. We had a fine, critical dialogue ... Increasingly - and especially with international students - you discover that this is not going to happen. Not in three or four years, maybe not at all." (Supervisor 1, A).

Other circumstances may challenge supervisors who are mainly inspired by the market perspective. Here, productivity and effectiveness are central, and when these interests are squeezed, supervisors are challenged. An example is the lack of formal ways in which to introduce "probation" for PhD students making it possible to get rid of them in "a civilized way", if the PhD student does not live up to expectations. One supervisor clarifies the background for his wish for a probation period:

"I really like having PhD students, but not when things don't run smoothly. Then I am left with bad conscience and have to spend time working with that, and I don't want to ... I cannot allow myself to say, You are doing too poorly and just let things be ... I also can't hand the student on to someone else. To terminate is such a damned heavy piece of machinery... The easiest thing is to let the process run its course, but that's a terrible waste of money. ... How do we get rid of them?" (Supervisor 2, B).

The challenge of "adapting people culturally" may also interfere with effectiveness:

"I don't do things differently with different PhD students - I think, I have grown more cynical because of what I've learned. [I] only employ Chinese who have taken their master's degree in 
Europe, Then they have acclimatised to our culture ... I don't employ people directly from China ... It means too much overhead providing cultural adaptation too. I have tried to [go straight for it] using the best man on paper - a Chinese - and that was a heavy task ... You have to be their mentor for a long period of time, and you are free to choose that. But that is not what I want to do." (Supervisor 1, B).

Finally, concern for professional quality may interfere with the external cooperation, since market agendas may cause "academic novelty" to be "at the low end" in some PhD projects. The dilemma between productivity, efficiency, and market concerns on the one side and quality, social, and cultural concerns on the other side is the major challenge in this perspective. It does not become evident by supervisors stating that they end up on the wrong side regarding quality and time spent on the individual $\mathrm{PhD}$ student. It is more evident in the clear denouncement of one supervisor's "complacency" and the claim, that the supervisor is using $\mathrm{PhD}$ supervision as "a means of generating money".

To the supervisors who are inspired by the changing society perspective, one of the major challenges is keeping a "playful" element in supervision and to keep workload within acceptable limits:

"Preferably - what I would prefer to do, was to sit back... and not have to be so strict, and say: What would you like to do? That looks really interesting! Are you sure, this [topic] is that good? More playful and open. Maybe I will be able to do that in some years. Because then there is an environment here, and then one PhD student draws in the next ... [But right now I cannot] sit back." (Supervisor with a changing society perspective, V4 A).

"If I had known [how much work this would be], I'm not sure, I would have dedicated myself this wholeheartedly to [attracting so many international students.]" (Supervisor with a changing society perspective, V2 A).

Supervisors who are mainly inspired by this perspective spend a disproportionate amount of time on the supervision of (international) PhD students and may find it difficult to draw the line. This applies in particular to supervisors inexperienced with the supervision of international $\mathrm{PhD}$ students. This challenge is related to another, namely the challenge of relating to the cultural habits and work routines of $\mathrm{PhD}$ students, which can be rather time consuming (see Bøgelund, 2014). Finally it is related to a certain unwillingness to terminate processes which consume too many resources. As expressed by one of the supervisors, "Terminating someone is something I've been reluctant to do - but that is where I am now". In summary, the major challenge to supervisors adhering to the changing society perspective is limiting $\mathrm{PhD}$ supervision so it does not take resources form other tasks - or from the supervisor him or herself.

\section{Discussion}

As the empirical data show, the task of supervising $\mathrm{PhD}$ students has become more complex. As the university evolves and incorporates a new agenda with regards to the purpose and value of knowledge production, so supervisors have been asked to adapt to several new legitimate agendas. This study shows that the sole pursuit of academic and professional aims no longer dominates, whereas knowledge production from a market perspective gains ground. This is interesting when we compare it with the findings of Grant (2005). In her study, Grant identifies four discourses related to supervision of master students, which she names the psychological, the traditional academic, the techno-scientific, and the neo-liberal discourses. There is a large element of accordance between the two last mentioned discourses and knowledge production from a market perspective. Likewise the traditional academic discourse can be somewhat compared with knowledge production from an academic perspective, and the knowledge production mode of societal changes does have elements of the psychological discourse. Grant concludes that the 
psychological discourse is by far the most dominating, whereas the traditional academic 'does show' in her data, the techno-scientific 'never surfaced' and the neo-liberal 'appeared infrequently' (Grant, 2005, p. 8-9). It is noteworthy that her results seem to be in opposition to the results of this study, even if the categories do not compare entirely. There could be several explanations for this.

First of all, her study is carried out in the arts, humanities, and social sciences, whereas the supervisors of this study come from the technical sciences. Traditionally the technical science culture is characterized more by co-operation with and funding by external firms, and male and masculine norms of academic life (Johnson, Lee, \& Green, 2000). This is also reflected in the differences between the two programs in this study. Program B, characterized by classic technical disciplines, is dominated by the market perspective. Program A, at the interface of technology and social science, is more diverse. Secondly, there is a difference between supervising master students and $\mathrm{PhD}$ students. $\mathrm{PhD}$ students are more frequently part of research and often financed by external sources, thereby introducing more market driven agendas. Finally, the time difference between 2005 and 2012 may also explain why knowledge production from a market perspective dominates the perspective of the supervisors in this study and is hardly traceable in the study of Grant. The development towards tighter time limits, more external funding, more PhD students per supervisor, and more international students is a development that has increased and spread to more and more departments during the last ten years - as is also visible in the transformation of the two research programs in this study. The supervisors from program B said their transformation started 10 years ago, while the supervisors from program A said their transformation started only a couple of years ago.

One way or the other, the results of this study show that knowledge production related to PhDs is interpreted in several ways mirroring the different agendas of a modern university. It is also visible from the study that different perspectives have different values, challenges, and consequences. Ideally a university of today needs supervisors who pursue the values of all three perspectives. The results of this study, however, show a tendency towards the market perspective. Old fashioned virtues like contributing academically to a field and valuing professional passion are put under pressure by new productivity and efficiency demands, which affect the job satisfaction of some supervisors (See also Bianchetti \& Quartiero, 2010; Smith, 2012). On a greater scale it might also affect the quality of the research carried out, bearing in mind the comment from one supervisor that the "academic novelty" is "at the low end" in some PhD projects. In general all supervisors are put under pressure to make sure deadlines are kept and, in case of external funding, that expectations from outside are met. To $\mathrm{PhD}$ education as a whole, it is interesting if the data of the research thereby draw a general picture of a development towards more leadership and control by supervisors and stronger ties between $\mathrm{PhD}$ research and the supervisor's own research. This is mainly of interest in connection with the question of where decision-making regarding central choices in research processes can or should be placed - with the supervisor or with the $\mathrm{PhD}$ student - and what this means to the independence of the PhD student. A development towards a more controlling role for the $\mathrm{PhD}$ supervisor with greater responsibility for project contents and more teaching of culturally bound work routines also affects the supervisor's work conditions and his or her chances to cope with the facilitation of the professional development of an increasing number of $\mathrm{PhD}$ students.

The new agenda also presents other challenges to the role of the supervisor. These concern the cultural dimension. As is evident from the empirical data, supervisors react differently to the fact that international $\mathrm{PhD}$ students bring new habits, values, and modes of operation. Some supervisors make an effort to embrace and facilitate the understandings of international $\mathrm{PhD}$ students, whereas more supervisors consider the cultural exchange a burdensome and time demanding activity in the name of efficiency and productivity. In this respect the results of the study lean to- 
wards the results of researchers like Leathwood (2006) and Goode (2007). The efficient way of dealing with internationalization by some supervisors is to make sure international $\mathrm{PhD}$ students are not too unfamiliar with the ways research are carried out here a priori, e.g., by choosing only international students who have done a European master beforehand or spent some time as research assistant before starting the $\mathrm{PhD}$ study. In this sense internationalization and cultural exchange are not furthered. If we look at the two research programs, it cannot be concluded that extended exposure to internationalization (research program B) leads to increased cultural exchange: probably increased knowledge and more routines regarding the handling of challenges, but not a larger degree of openness. The question begging an answer is how international and open really are we in educating PhDs? And how much rationalisation efforts and tighter time limits mean in this connection? What are the consequences for international $\mathrm{PhD}$ students coming here? This cannot be answered based on this piece of research, but it would make an interesting topic in a research and education perspective.

\section{Conclusion}

This empirical inquiry examines how certain conditions bound by context - including the number and type of PhD students - exert influence on PhD supervisors' practice and self-image in a concrete professional connection; the Faculty of Engineering and Science at Aalborg University. As such, this inquiry carries the most validity in comparable professional research environments that experience similar agendas and conditions. In the profession of the humanities, for example, you will most probably find a different setting and context for the $\mathrm{PhD}$ supervisors, resulting in another distribution and nature of the knowledge production there. Given the exploratory nature of the inquiry, it can be seen as the initial examination of tendencies which are well-suited for further research. Regarding the data, it is worth mentioning that the two groups of researchers (in program A and program B, respectively) have been interviewed at two different stages of transition. This is an advantage in identifying understandings and practices in two different phases, but the lack of simultaneousness should be noted when drawing conclusions (Olsen \& Pedersen, 1997, p. 190).

The questions that have been addressed in this article are the following: What is the understanding of $\mathrm{PhD}$ supervisors with regards to the purpose of $\mathrm{PhD}$ related knowledge production? How do they actually practice based on that understanding? The larger purpose being to investigate what consequences the current trends have for the working conditions of the PhD supervisors and the education of $\mathrm{PhD}$ students at large.

The empirical evidence shows that it has become more complex to be a $\mathrm{PhD}$ supervisor. Ideally the university has several legitimate agendas, which the supervisors are asked to balance, not necessarily in a single $\mathrm{PhD}$ project, but at least at a more aggregated level. Three knowledge perspectives are identified in this study: knowledge production in an academic perspective, knowledge production in a market perspective, and knowledge production in a changing society perspective. Each embracing a specific university agenda: 1) High quality research, 2) Economic viable and efficient research, and 3) Internationally relevant change agency research. Ideally each of these perspectives corresponds to a specific role and focus as a supervisor: 1)The role as professional sparring partner focusing on motivation and professional guidance, 2) The role as project leader focusing on the production of usable results, and 3) The role as an all-round facilitator focusing on the ability of the $\mathrm{PhD}$ student to understand and reflect on theory and put it to practical use in a new context.

The research shows that, currently, knowledge production in a market perspective is the dominating perspective, putting the two other perspectives under pressure. For instance, knowledge production in an academic perspective is put under pressure by more strict deadlines and more narrow agendas and calls for productivity. Knowledge production in a changing society perspective 
is likewise put under pressure by the work load related to facilitating international $\mathrm{PhD}$ students into change agents and the corresponding lack of resources put into the task by the university management. The top concern from a market perspective is how to introduce probation for $\mathrm{PhD}$ students, so it becomes possible to terminate students that do not perform well.

For the education of PhD students as such, the current development implies a more leading and visible role for the supervisor, even in terms of what to study, giving the supervisor a more central and responsible part compared to earlier. It also implies an increased pressure on academic quality. What all this means to the PhD students is an interesting question to pursue from here. Surely different knowledge perspectives will affect $\mathrm{PhD}$ students in different ways.

\section{References}

Argyris, C., \& Schön, D. (1974). Theory in practice: Increasing professional effectiveness. San Francisco: Jossey-Bass Publishers.

Barnett, R. (1994). The limits of competence. Buckingham: Open University Press.

Barnett, R. (2011). Being a university. London: Routledge.

Bianchetti, L., \& Quartiero, E. M. (2010). Researchers under pressure: A comparative study of new forms of producing, advising and transmitting knowledge in Brazil and the European Union. European Educational Research Journal, 9(4), 498-509.

Buchanan, J., Gordon, S., \& Schuck, S. (2008). From mentoring to monitoring: The impact of changing work environments on academics in Australian universities. Journal of Further and Higher Education, $32(3), 241-250$.

Bøgelund, P. (2011). Kompetenceløft af ph.d.-vejlederen i en interkulturel virkelighed - Forbedring af praksis og viden omkring supervisio $n$ af udenlandske ph.d.-studerende [Skills enhancement of the $\mathrm{PhD}$ supervisor in an intercultural reality - Improvement of practice and knowledge surrounding the supervision of foreign $\mathrm{PhD}$ students]. [Project description].

Bøgelund, P. (2014). Flere og mere internationale ph.d.-studerende - Hvad betyder det for ph.d.vejledningen? [More PhD students and more international $\mathrm{PhD}$ students - What does this mean for $\mathrm{PhD}$ supervision?]. Dansk Universitetspcedagogisk Tidsskrift, 9(16), 144-154.

Delamont, S., Atkinson, P., \& Parry, O. (2004). Supervising the doctorate. A guide to success (2nd ed.). Maidenhead: The Society for Research into Higher Education and Open University Press.

Dunleavy, P. (2003). Authoring a PhD. How to plan, draft, write and finish a doctoral thesis or dissertation. China: Palgrave study guides.

Dysthe, O. (2002). Professors as mediators of academic text cultures: An interview study with advisors and master's degree students in three disciplines in a Norwegian university. Written Communication, 19(4), 493-544.

Eley, A., \& Jennings, R. (2005). Effective postgraduate supervision. Improving the student/supervisor relationship. Maidenhead: Open University Press.

Forsknings- og Innovationsstyrelsen. (2011). Evaluering af forskerkarriereveje- håndtering af forskeres karrierer på de danske universiteter [Evaluation of research career ways - Handling of researchers' careers at Danish universities]. København: Forsknings- og Innovationsstyrelsen.

Gardner, S. K. (2008). "What's too much and what's too little?" The process of becoming an independent researcher in doctoral education. The Journal of Higher Education, 79(3), 326-350.

Gibbons, M., Limoges, C., Nowotny, H., Schwartzman, S., Scott, P., \& Trow, M. (1994). The new production of knowledge. The dynamics of science and research in contemporary societies. London: SAGE Publications Ltd. 
Goode, J. (2007). Empowering or disempowering the international Ph.D. student? Constructions of the dependent and independent learner. British Journal of Sociology of Education, 28(5), 589-603.

Grant, B. (2005). The pedagogy of graduate supervision: Figuring the relations between supervisor and student. Auckland: The University of Auckland.

Handal, G., \& Lauvås, P. (2006). Forskningsveilederen. Oslo: Cappelen Akademisk Forlag.

Jamison, A., Christensen, S. H., \& Botin, L. (2011). A hybrid imagination. Science and technology in cultural perspective. London: Morgan \& Claypool Publishers.

Johnson, L., Lee, A., \& Green, B. (2000). The PhD and the autonomous self: Gender, rationality and postgraduate pedagogy. Studies in Higher Education, 25(2), 135-147.

Jones, M. (2013). Issues in doctoral studies - Forty years of journal discussion: Where have we been and where are we going? International Journal of Doctoral Studies, 8, 83-104. Retrieved from http://ijds.org/Volume8/IJDSv8p083-104JonesFT129.pdf

Kolmos, A., \& Holgaard, J. E. (2007). Situationsbaseret projektvejledning [Situation-based project supervision]. Dansk Universitetspcedagogisk Tidsskrift, 3, 54-62.

Leathwood, C. (2006). Gender, equity and the discourse of the independent learner in higher education. Higher Education, 52, 611-633.

Lee, A. (2008). How are doctoral students supervised? Concepts of doctoral research supervision. Studies in Higher Education, 3, 267-281.

Lindén, J. (1998). Handledning av Doktorander [Supervision of PhD students]. Nora: Bokförlaget Nya Doxa.

Meyer, L. H. (2012). Negotiating academic values, professorial responsibilities and expectations for accountability in today's university. Higher Education Quarterly, 66(2), 207-217.

Olsen, P. B., \& Pedersen, K. (1997). Problemorienteret projektarbejde-en varkstøjsbog [Problem oriented project - A toolbook]. Frederiksberg: Roskilde Universitetsforlag.

Rugg, G., \& Petre, M. (2004). The unwritten rules of PhD research. Maidenhead: Open University Press.

Smith, M. J (2012). Transforming traditions: A study of researchers in higher education. Journal of Further and Higher Education, 36(2), 187-203.

Schniederjans, M. J. (2007). A proposed Ph.D. student bill of rights. International Journal of Doctoral Studies, 2, 1-8. Retrieved from http://www.ijds.org/Volume2/IJDSv2p001-008Schniederjans22.pdf

Sursock, A., \& Smidt, H. (2010). Trends 2010: A decade of change in European higher education. Brussels: European University Association.

Taylor, S., \& Beasley, N. (2005). A handbook for doctoral supervisors. New York: Routledge.

Wenneberg, S. B. (2001). Vidensledelse på universiteterne - når viden både skal produceres og anvendes [Knowledge management in universities - when knowledge both be produced and used.]. Ledelse og Erhvervsøkonomi, 1, 39-48.

Wichmann-Hansen, G., Eika, B., \& Mørcke, A. M. (2007). Hvad findes der af litteratur om vejledning? Litteratursøgning med fokus på publicerede, evidensbaserede studier [What literature is available on supervision? - Literature search focused on published evidence-based studies.] Dansk Universitetspadagogisk Tidsskrift, 3, 11-19. 


\section{Biography}

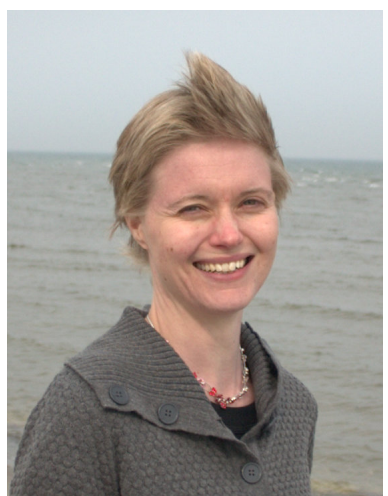

Pia Bogelund is an Assistant Professor at the Department of Planning at Aalborg University. Her current fields of research are supervision of international $\mathrm{PhD}$ students and group dynamics related to problem based learning projects. She has published on the facilitation of independent international students, skills development of supervisors and conflict management related to group work. She works with the training and skills development of university staff and researchers as concerns $\mathrm{PhD}$ supervision, professional communication and project planning. She also works as a coach for the PhD students at the Faculty of Engineering and Science. She holds a Master degree in Planning, a $\mathrm{PhD}$ in Planning and is trained as coach and psychotherapist as well. 